\title{
THE DETERMINANTS OF FOREIGN DIRECT INVESTMENT: A VECM APPROACH
}

\author{
Silky Vigg Kushwah, Manan Garg, \\ New Delhi Institute of Management, India
}

\begin{abstract}
The paper investigates the nexus between foreign direct investment (FDI) and macroeconomic variables namely trade openness, oil prices, stock index returns, GDP, exchange rate in India. FDI is considered as the dependent variable whereas macroeconomic variables are considered as independent variables. Using the Vector error correction model (VECM), we examine both the short-run and long-run relationship between FDI and macroeconomic variables over the period 2007-2019. Based on the existing literature, interest rate and inflation are considered as the controlled variables in the study. Co-integration is found in the time series variables using the Johansen Co-integration test and hence, restricted VAR (VECM) is applied to examine the nexus. Empirical evidence indicates that neither there is long term nor short term relationship between FDI inflows and underlying macroeconomic variables of the study. Although, the results highlight that FDI is significantly and positively influenced by its own lags. Therefore within the specified scope, the study suggests that liberal and flexible government policies on foreign investment may not only mark a surge in FDI inflows but will also encourage further investments by foreign individuals and companies in India.
\end{abstract}

Keywords: Foreign direct investment (FDI), macroeconomic variables, co-integration, vector error correction model (VECM)

\section{Introduction}

FDI has a crucial role in the overall development of a nation (UNCTAD, 2003). It not only drives economic growth but also results in other immense benefits like productivity increase, employment opportunities, supplier of non-debt financial resources, developed infrastructure, technological advancement, and domestic currency stability (Campos \& Kinoshita, 2002; Kim et al., 2003; Johnson, 2006; Busse \& Groizard, 2008; Krifa-Schneider \& Matei, 2010; Walsh \& Yu, 2010; Alfaro et al., 2010; EBRD, 2002). Since the LPG policy, 1991 (Liberalization, privatization, and globalization) in India, a lot of movement has been seen in foreign investment. Over the last decade, the Indian government has initiated numerous measures to make FDI policies flexible and investors friendly so that more and more foreign investments take place in the economy. Many vital sectors of the Indian economy are open for FDI under automatic route wherein a foreign individual or a foreign 
company doesn't need to take prior permission for investment from the central bank or government. For the past few years, a major part of Indian FDI inflows comes from nations like Mauritius, Singapore, Japan, the UK, the Netherlands, the US, Germany, Cyprus, France, and the UAE.

India received the maximum FDI equity inflows from Singapore (US\$ 11.65 billion), followed by Mauritius (US\$ 7.45 billion), Netherlands (US\$ 3.53 billion), Japan (US\$ 2.80 billion) and USA (US\$ 2.79 billion) during 2019-20. The sectors that witness maximum foreign investments include services, computer hardware and software, construction development, trading, automobile, pharmaceuticals, chemicals, and power. India's FDI equity inflows were US\$ 456.79 billion from April 2000 to December 2019, according to the Department for Promotion of Industry and Internal Trade (DPIIT). India's FDI equity inflows were US\$ 36.79 billion during AprilDecember 2019 ("Foreign Direct Investment (FDI)," 2020).

Although, in the past two decades, FDI inflows in India have witnessed tremendous growth still there is a long road ahead to reach the top of FDI recipients. There are some key drivers for a foreign individual or a foreign company to engage in FDI in a host country. It becomes extremely important for a host country to understand the impact of these major underlying forces on the FDI inflows. With this background, we are not surprised to see numerous empirical research conducted to examine the determinants of foreign direct investment. In this study, we analyze the impact of a series of important determinants that previous research have identified including trade openness, oil prices, stock index returns, GDP, exchange rate on FDI inflows in India. Knowledge of the influence of such determinants seems crucial for an economy to boost its FDI. The policymakers may take appropriate measures, policy changes, etc to focus more on factors that work in favor of the FDI inflows.

This paper extends the existing literature in many ways. Firstly, earlier studies have conducted cross-country regressions to determine the impact of factors attracting FDI. But the question that strikes our mind is that the impact of economic variables on FDI may vary from economy to economy i.e. a particular macroeconomic variable may have an impact on one economy and may not impact other economies at all. Moreover, the degree of impact of a particular determinant on FDI may differ for different economies. It's because of the vast diversity in the socio, economic, political, and geographical and other factors. Also, some economies are developed, some are developing and others are underdeveloped. This variation in the economies may also create a difference in the impact of every determinant on FDI. Secondly, after going through the literature, another issue that comes into light is that the results of earlier studies are controversial and not conclusive in terms of the relative importance of each determinant and also the direction of impact of these determinants of FDI. This dearth of consensus might be justified in terms of the diversified sample collection, methodologies, and analytical tools, etc. The abovementioned 
issue makes enthusiastic readers, especially policymakers, researchers, and decisionmakers puzzled about utilizing the conclusions of such studies for their work. It, therefore, becomes necessary to conduct a study purely focusing on a developing economy, India, and investigating the impact of its key determinants on FDI inflows. Lastly, we employ the latest and well established econometric model, vector error correction model (VECM) to analyze the impact of selected macroeconomic variables on FDI.

So, the current study tries to examine the impact of potential determinants (that have been identified from existing literature) on FDI with special reference to India. These factors are trade openness, GDP, exchange rate, inflation, interest rates. The study includes two new factors affecting FDI, profitability, and oil prices and investigates both the short-run and long-run equilibrium relationship between FDI and the abovementioned macroeconomic variables in a developing economy, India. The findings of this study provide robust empirical evidence indicating lagged FDI as the only determinant of FDI in India. All other variables of the study have proved insignificant and do not influence FDI in India. These findings are vital for both future research as well as policymakers.

The rest of the paper is structured as follows: Section 2 presents a review of research; section 3 defines the data and the methodology employed in order to examine the relationship between FDI and underlying macroeconomic factors; section 4 reports the empirical results; and, section 5 is the conclusion,
International Journal of Accounting \& Business Finance Vol.6.No.2 December 2020 Issue. pp. 55 - 70

providing useful insights regarding the policy implications of the empirical findings.

\section{Literature Review}

A growing strand of literature exists to explore and analyze FDI attractiveness determinants. One of the important macroeconomic variables that influence FDI inflows has been identified in the literature as the market size of the host economy that is usually associated with the GDP (Bevan and Estrin, 2004). Numerous studies have highlighted a positive and significant relationship between FDI and market size that means higher the GDP of the host country, more are the FDI inflows (Bandera \& White, 1968; Schmitz \& Bieri, 1975; Swedenborg, 1979; Lunn, 1980; Dunning, 1980; Root \& Ahmed, 1979; Kravis \& Lipsey, 1982; Nigh, 1985; Schneider \& Frey, 1985; Culem, 1988; Papanastassiou \& Pearce, 1990; Wheeler \& Mody, 1992; Sader, 1993; Tsai, 1994; Shamsuddin, 1994; Billington, 1999; Pistoresi, 2000; Arbatli, 2011; Frey, 1984; Moore, 1993; Pfefferman \& Madarassy, 1992; Schneider \& Frey, 1985; Wang \& Swain, 1995).

Another macroeconomic variable influencing FDI, highlighted by earlier studies is the growth rate. A significant positive impact of growth rate is seen on FDI inflows (Krifa-Schneider \& Matei, 2010; Arbatli, 2011; Bandera \& White, 1968; Lunn, 1980; Schneider \& Frey, 1985; Culem, 1988; Billington, 1999). In contrast, few studies suggest that there is no role of the growth rate of the economy on FDI decision (Nigh, 1988; Tsai, 1994). Studies also throw light on inflation as one of the determinants of FDI (Krifa-Schneider \& Matei, 2010; Walch \& W€orz, 2012). According to the studies, there 
exist a negative relationship between inflation and FDI. Higher inflation is taken as higher market instability and is also associated with increased political or country risk which in turn guides a foreign individual or company to think twice before investing in such an economy. Moreover, the consequence of a higher inflation rate is a fall in the real rate of investment which again makes it unattractive for FDI (Schneider \& Frey, 1985; Trevino \& Mixon, 2004).

Trade openness is also considered to be a crucial determinant of FDI inflows in the host country (Scaperlanda \& Mauer, 1973; Scaperlanda \& Balough, 1983; Scaperlanda, 1992; Janicki \& Wunnava, 2004; KrifaSchneider \& Matei, 2010; Masron \& Abdullah, 2010; Kravis \& Lipsey, 1982; Culem, 1988; Edwards, 1990; Pistoresi, 2000). It is argued that high trade openness reflects a liberal and flexible trade policy of the economy which attracts more foreign investments. Although, there are studies that highlight an insignificant relationship between trade openness and FDI (Walsh \& Yu, 2010; Schmitz \& Bieri, 1972; Wheeler \& Mody, 1992). Studies also throw light on another macroeconomic variable, exchange rate. Some studies highlight that there exists a negative relationship between the exchange rate and FDI inflows (Caves, 1988; Contractor, 1990; Froot \& Stein, 1991; Blonigen, 1995; Blonigen \& Feenstra, 1996). In contrast to that, some studies suggest an insignificant impact of the exchange rate on FDI inflows (Calderon-Rossell, 1985; Sader, 1991; Blonigen, 1997; Tuman \& Emmert, 1999). The interest rate of the host country is considered as one of the factors affecting
FDI inflows, a higher interest rate in the host country results in lower domestic investments and simultaneously results in boosting FDI inflows as the expectations on return increases (Clegg, 1987; Grubaugh, 1987; Krykilis \& Pantelidis, 2003; Lall, 1980; Prugel, 1981).

After going through vast literature on determining the impact of factors attracting FDI, it is witnessed that there is a severe lack of consensus as the empirical studies are not only extensive but they are not conclusive too as to the relative importance and the direction of impact of the macroeconomic variables on FDI inflows. Moreover, past studies have wide differences in perspectives, methodologies, sample-selection, and analytical tools. There is wide evidence recognizing the effect of GDP, trade openness, inflation, real exchange rate, infrastructure, economic and political conditions on FDI (Camurdan \& Cevis, 2009; Mottaleb \& Kalirajan, 2010; Sekkat \& Veganzones- Varoudakis, 2007; Majeed \& Ahmad, 2009; Kok \& Ersoy, 2009; Ranjan \& Agrawal, 2011).

This study focusses on investigating the impact of some of the abovementioned variables on FDI and also introduces two new variables, profitability and oil prices to analyze their relationship with FDI. By profitability, it means that when the domestic companies of the host country witness high profits or return on investment than foreign companies also find it worth investing in this host country as compared to other countries. Higher profits are reflected in the stock returns of the companies so stock index return is considered as the variable for profitability. It has also been witnessed that 
International Journal of Accounting \& Business Finance Vol.6.No.2 December 2020 Issue. pp. 55 - 70

if the oil prices in the host country are high than the overall cost of production surges and this reduces the overall earnings, in turn, resulting in making the FDI inflows less attractive. So, both these variables, stock index return, and oil prices are also examined as the independent variables in the study.

\section{Data and Methodology}

The current study is an attempt towards investigating the impact of macroeconomic determinants on FDI inflows in India. We employ monthly data from 2007 to 2019 for the time series of potential FDI's drivers that have been identified as the most relevant in the literature. After going through the literature, it is also considered to take some factors as control variables. We test for both the long run and short-run impact of determinants, trade openness, exchange rate, gross domestic product (GDP), stock market index returns, and oil prices on FDI inflows in the Indian context. This study becomes very essential in the current context to analyze which determinants, India as a nation should focus more to enhance FDI inflows. Interest rates and inflation have been incorporated as control variables in this study. Indian data for GDP, interest rate, inflation, exchange rate have been extracted from the website of the central bank of India, Reserve Bank of India (RBI). Trade i.e. export and import of India have been extracted from the website, Trademap. Trade openness has been calculated using formula, (exports-imports)/GDP. FDI inflows in India have been extracted from DIPP, Department of Commerce, monthly data for oil prices is obtained from Brent Crude prices, a national level stock index of India, NIFTY's monthly closing prices have been extracted from the website of the Indian stock exchange, National Stock Exchange (NSE). Log returns of stock index prices and the natural log of all other variables have been calculated to remove the problem of heteroscedasticity.

The standard methodology employed in related studies is based on the estimation of the time series model for the country under investigation. In our case the time series model used, to examine the impact of FDI inflows' determinants is structured as follows:

$F D I=\beta 0+\beta 1 T O+\beta 2 E R+\beta 3 G D P+\beta 4 S R+$ $\beta 5 O I L P+\beta 6 \mathrm{INF}+\beta 7 \mathrm{INT}+\varepsilon \ldots . .(1)$

The logarithmic transformation of Eq. (1) is given by

$\ln F D I=\beta 0+\beta 1 \ln T O+\beta 2 \ln E R+\beta 3 \ln G D P+$ $\beta 4 \ln S R+\beta 5 \ln O I L P+\beta 6 \ln I N F+\beta 7 \ln I N T+$ $\varepsilon \ldots .(2)$

where FDI refers to the total monthly foreign direct investments in India, TO refers to trade openness based on monthly exports, monthly imports and monthly GDP, ER refers to exchange rate of Indian rupee vs US dollar, SR refers to the stock index, NIFTY returns based on monthly closing prices and OILP refers to the monthly purchase price of oil by India, GDP is the monthly data for Gross Domestic Product, INF is the monthly Consumer Price Index indicating Inflation and INT are the monthly interest rates of India. Thus, to examine the relationship, the methodology reflected in figure-1 has been applied. 
Figure-1 Methodology

Source: Author's presentation

Based on the modern econometric model, the impact of some macroeconomic variables on FDI inflows in India has been examined in this study. One of the models that can be used is the Vector autoregressive model (VAR). It, however, comes with an assumption of stationarity of the time series data employed in the study. If the time series are found nonstationary, the stability form required for VAR is not met, indicating that the test statistic of Granger causality is inacceptable. In this scenario of non-stationarity data, one can calculate the first difference of the time series and use them for applying VAR. Although, in economic theory, doubts are raised about the economic model after differencing and the results are not considered strong. The other method that can be employed is to examine the co-integration between the time series data (Yoo \& Ku, 2009). This can be analyzed
International Journal of Accounting \& Business Finance Vol.6.No.2 December 2020 Issue. pp. 55 - 70

using the Johansen co-integration test. In case the nonstationary data is found cointegrated, the Vector error correction model (VECM) is recommended. A vector error correction (VEC) model is a restricted VAR model used when the series are nonstationary and cointegrated. So, it becomes indispensable to test the stationarity and then the co-integration of the time series in our study to understand which econometric model fits best for the estimation.

\subsection{Descriptive Statistics}

All the time series data used in the study have been examined for normality using descriptive and Jarque Bera normality test. These descriptive statistics are depicted in Table-1. It is seen that the ratio between mean and median is quite low and near to 1 . The difference between maximum and minimum values is also less. The Jarque-Bera statistics also highlight the normality of the variables chosen.

Table-1: Descriptive Statistics

\begin{tabular}{|c|c|c|c|c|c|c|c|c|}
\hline Series Name & LEXR & LFDI & LGDP & LINF & LINT & LOIL & LSR & LTO \\
\hline Observation & 156 & 156 & 156 & 156 & 156 & 156 & 156 & 156 \\
\hline Mean & 1.744372 & 4.121308 & 2.000428 & 1.919652 & 0.841658 & 1.860843 & 0.01533 & 3.469483 \\
\hline Median & 1.773521 & 4.109289 & 2.000329 & 1.950007 & 0.812913 & 1.866376 & 0.002262 & 3.546258 \\
\hline Maximum & 1.868997 & 4.709253 & 2.011202 & 2.177248 & 1.010724 & 2.123296 & 1.945678 & 3.797552 \\
\hline Minimum & 1.593231 & 3.454692 & 1.988776 & 1.68647 & 0.778151 & 1.473925 & -0.11856 & 3.014633 \\
\hline Stdev & 0.08178 & 0.267082 & 0.005526 & 0.12758 & 0.072986 & 0.144364 & 0.158334 & 0.187302 \\
\hline skewness & -0.30469 & -0.07639 & 0.192286 & -0.23712 & 0.729965 & -0.28244 & 11.79579 & -0.76873 \\
\hline Kurtosis & 1.669748 & 2.420531 & 2.340907 & 2.05879 & 1.920181 & 2.174518 & 144.3983 & 2.46158 \\
\hline Jarque-Bera & 13.91595 & 2.334305 & 3.784937 & 7.220093 & 21.4331 & 6.503271 & 132719 & 17.24881 \\
\hline Probability & 0.000951 & 0.011252 & 0.050699 & 0.027051 & 0.000022 & 0.038711 & 0.000000 & 0.00018 \\
\hline
\end{tabular}

Source: Authors Calculations 


\subsection{Correlation Matrix}

To understand the existence of a relation between the variables of the study, a correlation matrix is also formed. Refer to table 2. It is seen that FDI is positively correlated with the exchange rate and trade openness and
International Journal of Accounting \& Business Finance Vol.6.No.2 December 2020 Issue. pp. 55 - 70 negatively correlated with oil prices. Though, no significant correlation exists between the FDI and other macroeconomic variables of the study.

Table-2: Correlation Matrix

\begin{tabular}{|c|c|c|c|c|c|c|c|c|}
\hline Probability & LEXR & LFDI & LGDP & LINF & LINT & LOIL & LTO & LSR \\
\hline LEXR & 1 & 0.678 & -0.411 & 0.947 & $0.429 * *$ & $-0.459^{* *}$ & $0.869^{* *}$ & 0.100 \\
\hline LFDI & 0.678 & 1 & -0.197 & 0.670 & $0.094^{* *}$ & $-0.414^{* *}$ & $0.578^{* *}$ & 0.047 \\
\hline LGDP & -0.411 & -0.197 & 1 & -0.268 & $-0.446^{* *}$ & $0.062^{* *}$ & $-0.344^{* *}$ & -0.063 \\
\hline LINF & 0.947 & 0.670 & -0.268 & 1 & $0.373^{* *}$ & $-0.343^{* *}$ & $0.915^{* *}$ & 0.155 \\
\hline LINT & $0.429 * *$ & $0.094 * *$ & $-0.446^{* *}$ & $0.373^{* *}$ & 1 & $0.186^{* *}$ & $0.519^{* *}$ & 0.155 \\
\hline LOIL & $-0.459^{* *}$ & $-0.414^{* *}$ & $0.062^{* *}$ & $-0.343^{* *}$ & $0.186^{* *}$ & 1 & $-0.062^{* *}$ & -0.029 \\
\hline LTO & $0.869^{* *}$ & $0.578^{* *}$ & $-0.344^{* *}$ & $0.915^{* *}$ & $0.519^{* *}$ & $-0.062^{* *}$ & 1 & 0.074 \\
\hline LSR & 0.100 & 0.047 & -0.063 & 0.155 & -0.011 & -0.029 & 0.074 & 1 \\
\hline
\end{tabular}

* Significant at $10 \%, * *$ Significant at $5 \%, * * *$ Significant at $1 \%$ level of significance

Source: Authors Calculations

It is crucial to understand that in the case of a non-stationary series, the findings and inferences from the regression are spurious and hence useless. Thus, the stationarity of the time series data has been examined. Nelson and Plosser (1982) propose a method to detect the stationarity of the time series and the stochastic trend if any. A stochastic trend is determined by testing the existence of unit roots in time series data (Elliot, Rothenberg, \& Stock, 1996; Dritsaki \& Dritsaki-Bargiota, 2005). Two unit root tests, Augmented Dickey-Fuller test and Phillips-Perron test have been applied on the time series data to check the robustness. The details have been summarized in the section on empirical results. The Augmented DickeyFuller model is:

$$
\Delta \mathrm{Z}_{t}={ }_{1+2} t+{ }_{3} Z_{t-1}+{ }_{i} \Delta \mathrm{Z}_{t-I}+\varepsilon_{t}
$$

where ADF regression tests for the existence of unit root of $\mathrm{Zt}$, the logarithmic values of all model variables at time $t$.

The Phillips-Perron model is:

$y_{t}=c+\delta t+a y_{t-1}+e(t)$

where $e(t)$ is the innovations process. The test assesses the null hypothesis under the model variant appropriate for series with different growth characteristics $(c=0$ or $\delta=0)$.

In practice, if the time series comes out to be non-stationary, it is converted into stationary by differencing for further empirically examining the series. Although, in economic theory, doubts are raised about the economic model after differencing. Engel and Granger (1987) revealed that to examine non-stationary series at level, all the data series are integrated 
at the same order and co-integrated. According to their study, in the case of co-integrated series, long-run equilibrium relationship may exist even in the case of non-stationary data (Dickey, Jansen, \& Fuller, 1991). So, Granger (1986) suggested that to avoid spurious results of regression analysis, the co-integration test becomes crucial (Engle \& Yoo, 1987). Thus, the co-integration test is applied to the data series.

In our study, the Johansen Fisher test for assessing co-integration is applied to the data series. The details have been summarized in the section on empirical results. The hypothesis that tests this is the null of non-cointegration against an alternative that co-integration exists. This test uses the maximum likelihood procedure to test for cointegrating vectors in non-stationary time series as a VAR. Consider a VAR of order $\mathrm{k}$

$Y t=A 1 Y t 1+A 2 Y t 2+\ldots \ldots \ldots+A k Y t k+B X t$ $+f t--$ - (3)

Where,

$\mathrm{Yt}=\mathrm{a}$ k-vector of non-stationary I (1) variables, $\mathrm{Xt}=$ the vector of deterministic variables,

Here, $\mathrm{Yt}$ is a vector of non-stationary variables. The information available from the coefficient matrix between the levels of the series $\Pi$ can be expressed as $\Pi=\mathrm{ab}^{\prime}$ where a matrix contains adjustment coefficients and the $b$ matrix contains the cointegrating vectors. There are two likelihood ratio test statistics specified by Johansen and Juselius (1990) to test the number of cointegrating vectors. The first likelihood ratio is the Maximum Eigenvalue statistic that tests for the null of exactly $r$ cointegrating vectors against the alternative of $r+1$ vectors. The second is Trace statistic that tests for the hypothesis of at most $r$ cointegrating vectors against the alternative of $r+1$ vectors. The null hypothesis is the absence of a cointegrating relationship, that is, $r=0$ and $r \leq 1$.

The results of stationarity and co-integration finally determine the model (VAR/ VECM) we then use to highlight both the short-run and long-run impact of selected determinants on FDI inflows in India. The findings indicate that the time series variables are nonstationary (results are summarised in the next section) and have co-integration among them (results are summarised in the next section), so the final step to estimate the model of our study, vector error correction model (VECM) is used, which helps in deducing the Granger causal relationship between the variables. The VECM model is:

$$
\begin{aligned}
& \Delta y_{1, t}=\alpha_{1}\left(y_{2, t-1}-\beta y_{1, t-1}\right)+\epsilon_{1, t} \\
& \Delta y_{2, t}=\alpha_{2}\left(y_{2, t-1}-\beta y_{1, t-1}\right)+\epsilon_{2, t}
\end{aligned}
$$

In this simple model, the only right-hand side variable is the error correction term. In the long-run equilibrium, this term is zero. However, if $y_{1}$ and $y_{2}$ deviate from the longrun equilibrium, the error correction term will be nonzero and each variable adjusts to partially restore the equilibrium relation. The coefficient alpha measures the speed of adjustment of the $i$-th endogenous variable towards the equilibrium. An issue that occurs in estimating any VAR model is the proper specification of the model. We have used the Akaike Information Criterion (Akaike, 1974) 
and Schwarz Bayesian Criterion (Schwartz, 1978 ) to solve this difficulty (Maddala, 1992; Mills \& Prasad, 1992).

\section{Empirical results}

The present study examines the stationarity of the variables. The log-transformed data for FDI, exchange rates, trade openness, stock index returns, GDP, oil price, inflation, and interest rates are tested for stationarity. The findings are depicted in table-3. The results suggest that all the above-mentioned variables have a unit root at the level and are non-stationary. After transforming them to the first difference level, all the variables get converted into stationary.

Table-3: Summary of Unit Root Test

\begin{tabular}{|c|c|c|c|}
\hline Variables & Level & ADF -Fisher Chi-Square & Philip Perron test \\
\hline \multirow[t]{4}{*}{ Oil prices } & \multirow[t]{2}{*}{ Level } & $-2.43706^{* * *}$ & $-2.24528 * * *$ \\
\hline & & $(0.1334)$ & $(0.1914)$ \\
\hline & \multirow[t]{2}{*}{ First Diff } & $-8.38986^{* * *}$ & $-8.39266 * * *$ \\
\hline & & $(0.0000)$ & $(0.0000)$ \\
\hline \multirow{4}{*}{$\begin{array}{l}\text { Stock } \\
\text { index }\end{array}$} & \multirow[t]{2}{*}{ Level } & $-12.3826^{* * *}$ & $-12.3826^{* * *}$ \\
\hline & & $(0.0000)$ & $(0.0000)$ \\
\hline & \multirow[t]{2}{*}{ First Diff } & $-13.0847 * * *$ & $-150.838^{* * *}$ \\
\hline & & $(0.0000)$ & $(0.0001)$ \\
\hline \multirow[t]{4}{*}{ GDP } & \multirow[t]{2}{*}{ Level } & $-4.01592 * * *$ & $384.540 * * *$ \\
\hline & & $(0.0018)$ & $(0.0000)$ \\
\hline & \multirow[t]{2}{*}{ First Diff } & $-3.8953 * * *$ & $-150.838 * * *$ \\
\hline & & $(0.0027)$ & $(0.0001)$ \\
\hline \multirow{4}{*}{$\begin{array}{c}\text { Trade } \\
\text { Openness }\end{array}$} & \multirow[t]{2}{*}{ Level } & $-2.25633^{* * *}$ & $-24.9225^{* * *}$ \\
\hline & & $(0.1876)$ & $(0.0000)$ \\
\hline & \multirow[t]{2}{*}{ First Diff } & $-23.4322 * * *$ & $24.9225 * * *$ \\
\hline & & $(0.0000)$ & $(0.0000)$ \\
\hline \multirow[t]{4}{*}{ FDI } & \multirow[t]{2}{*}{ Level } & -4.00728 & $-6.15813^{* * *}$ \\
\hline & & $(0.0018)$ & $(0.0000)$ \\
\hline & \multirow[t]{2}{*}{ First Diff } & $10.8757 * * *$ & $-45.8568 * * *$ \\
\hline & & $(0.0000)$ & $(0.0001)$ \\
\hline \multirow[t]{4}{*}{ Inflation } & \multirow[t]{2}{*}{ Level } & $0.215776^{* * *}$ & $0.195858 * * *$ \\
\hline & & 0.9728 & $(0.9716)$ \\
\hline & \multirow[t]{2}{*}{ First Diff } & $-11.7628 * * *$ & $-11.7628 * * *$ \\
\hline & & $(0.0000)$ & $(0.0000)$ \\
\hline
\end{tabular}




\begin{tabular}{|c|c|c|c|}
\hline \multirow{3}{*}{$\begin{array}{c}\text { Exchange } \\
\text { rate }\end{array}$} & Level & $-0.70692 * * *$ & $-0.72593 * * *$ \\
\cline { 3 - 4 } & & $(0.8408)$ & $(0.836)$ \\
\cline { 3 - 4 } & First Diff & $-0.70692 * * *$ & $-11.2842 * * *$ \\
\cline { 3 - 4 } & & $(0.0408)$ & $(0.0000)$ \\
\hline \multirow{2}{*}{$\begin{array}{c}\text { Interest } \\
\text { Rate }\end{array}$} & \multirow{2}{*}{ Level } & $-1.76442 * * *$ & $-1.65027 * * *$ \\
\cline { 3 - 4 } & & $(0.397)$ & $(0.4545)$ \\
\cline { 3 - 4 } & \multirow{2}{*}{ First Diff } & $-12.0676 * * *$ & $-12.1727 * * *$ \\
\cline { 3 - 4 } & & $(0.0000)$ & $(0.0000)$ \\
\hline
\end{tabular}

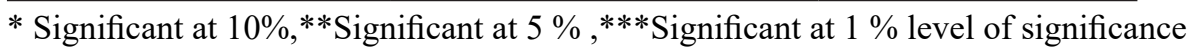

\section{Source: Authors Calculations}

Time series are stationary at the first order of integration and hence there arises a need to investigate co-integration. The study uses the Johansen co-integration test to examine the cointegration and the results obtained reject the null hypothesis. In other words, co-integration exists between the variables of the study as shown in table-4 below.

Table-4: Johansen Co-integration Test

\begin{tabular}{|c|c|c|}
\hline $\begin{array}{c}\text { Hypothesized } \\
\text { No. of Co- } \\
\text { integrating } \\
\text { Equations }\end{array}$ & Trace Stat & Probability \\
\hline None $*$ & $283.052^{* *}$ & 0.0000 \\
\hline At most $1 *$ & $152.622^{* *}$ & 0.0004 \\
\hline At most $2 *$ & $96.155^{* *}$ & 0.0469 \\
\hline At most 3 & $61.101^{* *}$ & 0.2031 \\
\hline At most 4 & $37.269^{* *}$ & 0.3349 \\
\hline At most 5 & $20.634^{* *}$ & 0.3808 \\
\hline At most 6 & $6.339 * *$ & 0.6554 \\
\hline At most 7 & $0.359^{* *}$ & 0.5491 \\
\hline
\end{tabular}

* Significant at $10 \%, * *$ Significant at $5 \%$ ,***Significant at $1 \%$ level of significance

Source: Authors Calculations
In the test for co-integration, it can be seen that the null hypothesis is not rejected at the atmost 3 levels as the probability is more than 0.05 and hence, co-integration exists in at most 3 variables in the data set. Thus, now it is advisable to use VECM to equation (2) for analyzing the impact of exchange rates, GDP, trade openness, stock index returns, oil prices, inflation, and interest rates on FDI inflows.

Based on nonstationary data and co-integration results, VECM suits best to analyze the nexus between FDI and macroeconomic variables and examine equation (2). Both the short-run and long-run relationships are examined. The estimated results of VECM are reported in equation 3 and Table 5. The most robust findings of our study confirm the positive impact of lagged FDI on FDI inflows. The econometric estimates also uncover statistically insignificant effects for all other variables of the study. The analysis finds the non-existence of long-run causality running from macroeconomic variables, exchange rate, trade openness, stock return, GDP, oil prices to FDI. Moreover, there is no influence of any macroeconomic variable on FDI in the short run too. 
$\mathrm{D}(\mathrm{LFDI})=\mathrm{C}(1)^{*}(\mathrm{LFDI}(-1)-$ 3.72498090511*LEXR(-1) - 8.14779359595 *LTO(-1) - 5.40660421599*LSR(-1) + 48.9630743631*LGDP(-1) +

$3.89006724334 *$ LOIL(-1)

$1.72475660206 *$ LINT(-1) + 14.0891430984 *LINF(-1) - $102.93843768 \quad$ ) + $\mathrm{C}(2) * \mathrm{D}(\mathrm{LFDI}(-1))+\mathrm{C}(3) * \mathrm{D}(\mathrm{LFDI}(-2))+$ $\mathrm{C}(4) * \mathrm{D}(\operatorname{LFDI}(-3))+\mathrm{C}(5) * \mathrm{D}(\operatorname{LEXR}(-1))+$ $\mathrm{C}(6) * \mathrm{D}(\operatorname{LEXR}(-2))+\mathrm{C}(7)$

$* \mathrm{D}(\operatorname{LEXR}(-3))+\mathrm{C}(8) * \mathrm{D}(\mathrm{LTO}(-1))+$

$\mathrm{C}(9) * \mathrm{D}(\mathrm{LTO}(-2))+\mathrm{C}(10) * \mathrm{D}(\mathrm{LTO}(-3))$

$+\mathrm{C}(11) * \mathrm{D}(\mathrm{LSR}(-1))+\mathrm{C}(12) * \mathrm{D}(\mathrm{LSR}(-2))+$ $\mathrm{C}(13) * \mathrm{D}(\operatorname{LSR}(-3))+\mathrm{C}(14)$

*D(LGDP(-1)) + C(15)*D(LGDP(-2)) + $\mathrm{C}(16) * \mathrm{D}(\operatorname{LGDP}(-3))+\mathrm{C}(17)$

$* \mathrm{D}(\mathrm{LOIL}(-1))+\mathrm{C}(18) * \mathrm{D}(\mathrm{LOIL}(-2))+$ $\mathrm{C}(19) * \mathrm{D}(\operatorname{LOIL}(-3))+\mathrm{C}(20) * \mathrm{D}(\operatorname{LINT}($

$-1))+\mathrm{C}(21) * \mathrm{D}(\operatorname{LINT}(-2))+$ $\mathrm{C}(22) * \mathrm{D}(\operatorname{LINT}(-3))+\mathrm{C}(23) * \mathrm{D}(\operatorname{LINF}(-1))+$ $\mathrm{C}(24) * \mathrm{D}(\operatorname{LINF}(-2))+\mathrm{C}(25) * \mathrm{D}(\operatorname{LINF}(-3))+$ $\mathrm{C}(26)$.........equation3

Table-5: VECM Model

\begin{tabular}{|c|c|c|}
\hline & Coefficient & Prob. \\
\hline $\mathrm{C}(1)$ & -0.0370 & 0.4172 \\
\hline $\mathrm{C}(2)$ & -0.5142 & 0 \\
\hline $\mathrm{C}(3)$ & -0.2928 & 0.003 \\
\hline $\mathrm{C}(4)$ & -0.1991 & 0.022 \\
\hline $\mathrm{C}(5)$ & -1.9645 & 0.2905 \\
\hline $\mathrm{C}(6)$ & -0.0799 & 0.9641 \\
\hline $\mathrm{C}(7)$ & 0.9316 & 0.5855 \\
\hline $\mathrm{C}(8)$ & 0.2346 & 0.6505 \\
\hline $\mathrm{C}(9)$ & 0.0267 & 0.9624 \\
\hline $\mathrm{C}(10)$ & -0.6050 & 0.1785 \\
\hline $\mathrm{C}(11)$ & -0.1396 & 0.7293 \\
\hline $\mathrm{C}(12)$ & -0.1582 & 0.6802 \\
\hline
\end{tabular}

\begin{tabular}{|c|c|c|}
\hline $\mathrm{C}(13)$ & 0.0035 & 0.9925 \\
\hline $\mathrm{C}(14)$ & -30.1721 & 0.6716 \\
\hline $\mathrm{C}(15)$ & -4.4358 & 0.9546 \\
\hline $\mathrm{C}(16)$ & 31.5171 & 0.7173 \\
\hline $\mathrm{C}(17)$ & -0.0703 & 0.891 \\
\hline $\mathrm{C}(18)$ & -0.0231 & 0.9655 \\
\hline $\mathrm{C}(19)$ & 0.1264 & 0.8104 \\
\hline $\mathrm{C}(20)$ & 0.0072 & 0.9933 \\
\hline $\mathrm{C}(21)$ & 1.1191 & 0.1913 \\
\hline $\mathrm{C}(22)$ & -1.0386 & 0.2291 \\
\hline $\mathrm{C}(23)$ & -1.5109 & 0.7541 \\
\hline $\mathrm{C}(24)$ & -1.1556 & 0.8181 \\
\hline $\mathrm{C}(25)$ & -3.1520 & 0.5191 \\
\hline $\mathrm{C}(26)$ & 0.0276 & 0.2604 \\
\hline
\end{tabular}

Source: Authors Calculations

To complement this model, a diagnostic test is also reported for $\mathrm{F}$ statistics, which is significant, serial correlation (LM test), which indicates the existence of no serial correlation, autoregressive conditional heteroskedasticity (ARCH test), which highlights no heteroskedasticity in residue and normality test (Jarque Bera test), which shows that the data is normally distributed. These results are provided in Table 6 . The observations confirm the stability of the model based on the nexus between FDI and macroeconomic variables, exchange rate, trade openness, stock return, GDP, oil prices. The results of this study are in contrast to most of the previous studies. The study highlights that FDI inflows in India are not influenced by selected macroeconomic variables like exchange rate, GDP, trade openness, stock index returns, oil prices, inflation and interest rates which are dissimilar to the studies that argue that all the above-mentioned variables have a significant impact on FDI inflows (Camurdan \& Cevis, 
2009; Mottaleb \& Kalirajan, 2010; Sekkat \& Veganzones- Varoudakis, 2007; Majeed \& Ahmad, 2009; Kok \& Ersoy, 2009; Ranjan \& Agrawal, 2011). Moreover, the study also reveals that FDI is significantly affected by its own lag and this result is similar to that of Tripathi \& Seth (2105).

Table 6: Diagnostic test

\begin{tabular}{|c|c|}
\hline Residual Diagnostics & p-value \\
\hline Normality Test & 0.2349 \\
\hline Serial correlation Test & 0.1575 \\
\hline Heteroscedasticity test & 0.7786 \\
\hline F statistics & 0.0010 \\
\hline
\end{tabular}

Source: Authors Calculations

\section{Conclusion}

FDI inflows in India have witnessed a steep rise in the last few years. FDI brings great opportunities to the host company, most favorable are accomplishing technical knowhow and creating employment. The Indian government has also maintained a promising policy regime for boosting FDI inflows. Inspired by record FDI inflows, India is trying to be the favorite FDI destination in 2020 . The current study focuses on determining the impact of selected factors influencing FDI inflows in India. Some macroeconomic variables namely, exchange rate, GDP, trade openness, stock index returns, oil prices are considered as independent variables against FDI as the dependent variable. Inflation and interest rates are the control variables in the study. The study examines both the short-run and long-run relationship between FDI and macroeconomic variables using the Vector error correction model (VECM). Empirical evidence highlights that neither there exists a long term relationship nor a short term relationship between FDI and underlying macroeconomic variables of the study. The findings also highlight that FDI is influenced by its own lag.

The empirical results have important policy implications indicating the factor that the host economy should emphasize to attract FDI inflows. Surprisingly, the prominent determinants picked up from the existing literature namely exchange rate, GDP, trade openness, stock index returns, oil prices are not having a significant impact on FDI inflows in India. So, India may focus on factors other than the abovementioned determinants, whose impact may be examined in future research. Moreover, lagged FDI is indicated as one of the most robust determinants for the host economy.It is worth noting that India has achieved a $63^{\text {rd }}$ position on the World Bank's ease of doing business, jumping 14 places from $77^{\text {th }}$ position in the previous ranking. Perhaps, more reform efforts may help India to achieve its $50^{\text {th }}$ rank dream. Maybe opening more and more sectors under the automatic route will make FDI inflows easier and voluminous in the future. Future research may also focus on the qualitative analysis of India to further analyze the factors affecting its FDI attractiveness. It is also of particular importance to study the impact of other factors like political stability, tax regime, labor cost, human capital, and labor quality in India, using alternative proxies. Finally, future research on highlighting the impact of FDI determinants for different industry sectors may also be conducted. 


\section{References}

- $\quad$ Alfaro, L., Chanda, A., Kalemli-Ozcan, S., \& Sayek, S. (2010). Does foreign direct investment promote growth? Exploring the role of financial markets on linkages. Journal of Development Economics, 91(2), 242-256.

- $\quad$ Arbatli, M. E. (2011). Economic policies and FDI inflows to emerging market economies (No. 11-192). International Monetary Fund.

- $\quad$ Bandera, V. N., \& White, J. T. (1968). US direct investments and domestic markets in Europe. Economia Internazionale, 21(1), 117-233

- Bhasin, N., \& Jain, V. (2013). Home Country Determinants of Outward FDI: A Study of Select Asian Economies. Available at SSRN 2206739.

- Billington, N. (1999). The location of foreign direct investment: an empirical analysis. Applied Economics, 31(1), 65-76.

- $\quad$ Blonigen, B. A. (1995). Explaining Japanese Foreign Direct Investment in the United States. Unpublished Ph. D. Dissertation, University of California, Davis. Blonigen, B. A. (1997). Firm-specific Assets

- $\quad$ Blonigen, B. A. (1997). Firm-specific assets and the link between exchange rates and foreign direct investment. The American Economic Review, 447-465.

- Blonigen, B. A., \& Feenstra, R. C. (1996). Protectionist threats and foreign direct investment (No. w5475). National Bureau of Economic Research.
International Journal of Accounting \& Business Finance Vol.6.No.2 December 2020 Issue. pp. 55 - 70

- $\quad$ Busse, M., \& Groizard, L. (2008). Foreign direct investment, regulations and growth (World Bank Policy Research Working Paper Series No. 3882). Washington, DC: World Bank.

- Calderon-Rossell, J. R. (1985). Towards the theory of foreign direct investment. Oxford Economic Papers, 37(2), 282-291.

- Campos, N. F., \& Kinoshita, Y. (2002). Foreign direct investment as technology transferred: Some panel evidence from the transition economies. The Manchester School, 70(3), 398-419.

- $\quad$ Caves, R. E. (1988). Exchange-rate movements and foreign direct investment in the United States. Harvard Institute of Economic Research, Harvard University.

- Çeviş, İ., \& Çamurdan, B. (2009). The economical determinants of foreign direct investment (FDI) in developing countries and transition economies. e-Journal of New World Sciences Academy, 4(3), 3C0015.

- Cho, K. R., \& Nigh, D. (1988, May). Foreign direct investment and market concentration: the case of the commercial banking market in Malaysia. In Proceedings, Pan-Pacific Conference V (pp. 16-18).

- Clegg, J. (1987), Multinational Enterprises and World Competition, Macmillan, London.

- Contractor, F. J. (1990). Ownership patterns of US joint ventures abroad and the liberalization of foreign government regulations in the 1980s: Evidence from the benchmark surveys. Journal of International Business Studies, 21(1), 55-73. 
- Culem, C. G. (1988). The locational determinants of direct investments among industrialized countries. European economic review, 32(4), 885-904.

- Dunning, J. H. (1980). Explaining outward direct investment of developing countries: in support of the eclectic theory of international production. The University of Reading, Department of Economics.

- $\quad$ Foreign Direct Investment (FDI). (2020, May). Retrieved from https://www.ibef. org/economy/foreign-direct-investment. aspx\#: :text=During\%202019-20\%2C\%20 India $\% 20$ received,(US\%24\%202.79\%20 billion).

- $\quad$ Frey, B. S., \& Weck-Hanneman, H. (1984). The hidden economy as an 'unobserved' variable. European Economic Review, 26(12), 33-53.

- $\quad$ Froot, K. A., \& Stein, J. C. (1991). Exchange rates and foreign direct investment: an imperfect capital markets approach. The quarterly journal of economics, 106(4), 1191-1217.

- Grubaugh, S. G. (1987). Determinants of direct foreign investment. The Review of Economics and Statistics, 149-152.

- Janicki, H. P., \& Wunnava, P. V. (2004). Determinants of foreign direct investment: empirical evidence from EU accession candidates. Applied Economics, 36(5), 505-509.

- Johnson, A. (2006). FDI inflows to the transition economies in Eastern Europe: magnitude and determinants. The Royal
International Journal of Accounting \& Business Finance Vol.6.No.2 December 2020 Issue. pp. 55 - 70

Institute of Technology, CESIS (Centre for Excellence for Studies in Science in Innovation), Paper No, 59.

- $\quad$ Kim, D. D. K., \& Seo, J. S. (2003). Does FDI inflow crowd out domestic investment in Korea?. Journal of economic studies.

- $\quad$ Kok, R., \& Ersoy, B. A. (2009). Analyses of FDI determinants in developing countries. International Journal of Social Economics.

- $\quad$ Krifa-Schneider, H., \& Matei, I. (2010). Business climate, political risk and FDI in developing countries: Evidence from panel data. International Journal of Economics and Finance, 2(5), 54-65.

- Kyrkilis, D., Pantelidis, P. (2003). Macroeconomic Determinants of Foreign Direct Investment. International Journal of Social Economics,30(7), 827-836. doi: 10.1007/978-81-322-1536- 3

- $\quad$ Lall, S. (1980). Monopolistic advantages and foreign involvement by US manufacturing industry in The Multinational Corporation (pp. 3-28). Palgrave Macmillan, London.

- $\quad$ Lipsey, R. E., \& Kravis, I. (1982). US-owned affiliates and host-country exports.

- Lunn, J. (1980). Determinants of US direct investment in the EEC: Further evidence. European economic review, 13(1), 93-101.

- Lunn, J. (1983). Determinants of US direct investment in the EEC: Revisited again. European Economic Review, 21(3), 391-393. 
- $\quad$ Majeed, M. T., \& Ahmad, E. (2009). An Analysis of Host Country Characteristics that Determine FDI in Developing Countries: Recent Panel Data Evidence. Lahore Journal of Economics, 14(2).

- Masron, T. A., \& Abdullah, H. (2010). Institutional quality as a determinant for FDI inflows: evidence from ASEAN. World Journal of Management, 2(3), 115-128.

- $\quad$ Mottaleb, K. A., \& Kalirajan, K. (2010). Determinants of foreign direct investment in developing countries: A comparative analysis. Margin: The Journal of Applied Economic Research, 4(4), 369-404.

- Nigh, D. (1985). The effect of political events on United States direct foreign investment: A pooled time-series crosssectional analysis. Journal of International Business Studies, 16(1), 1-17.

- Papanastassiou, M., \& Pearce, R. D. (1990). Host country characteristics and the sourcing behavior of the UK manufacturing industry. The University of Reading, Department of Economics

- $\quad$ Pfefferman, G. P., \& Madarassy, A. (1992). Trends in private investment in developing countries, international finance corporation, and discussion" paper N0. 14. Washington D. $C$.

- $\quad$ Pistoresi, B. (2000). Foreign direct investment and localization factors: Latin America and the Southeast Asia. Rivista di Politica Economica, 90, 27-44.

- $\quad$ Prugel, T.A. (1981), "The determinants of foreign direct investment: an analysis of
International Journal of Accounting \& Business Finance Vol.6.No.2 December 2020 Issue. pp. 55 - 70

US manufacturing industries", Managerial and Decision Economics, Vol. 2, pp. 220-8.

- Ranjan, V., \& Agrawal, G. (2011). FDI inflow determinants in BRIC countries: A panel data analysis. International business research, 4(4), 255.

- $\quad$ Root, F. R., \& Ahmed, A. A. (1979). Empirical determinants of manufacturing direct foreign investment in developing countries. Economic development and cultural change, 27(4), 751-767.

- $\quad$ Sader, F. (1993). Privatization and foreign investment in the developing world. World Bank working paper, 1202.

- $\quad$ Sader, F. (1993). Privatization and foreign investment in the developing world. World Bank working paper, 1202.

- Scaperlanda, A. (1992). Direct investment controls and international equilibrium: the US experience. Eastern Economic Journal, 18(2), 157-170.

- $\quad$ Scaperlanda, A. E., \& Mauer, L. J. (1973). The impact of controls on the United States direct foreign investment in the European Economic Community. Southern Economic Journal, 419-423.

- $\quad$ Scaperlanda, A., \& Balough, R. S. (1983). Determinants of US direct investment in the EEC: Revisited. European Economic Review, 21(3), 381-390.

- $\quad$ Schmitz, A., \& Bieri, J. (1972). EEC tariffs and US direct investment. European Economic Review, 3(3), 259-270.

- $\quad$ Schneider, F., \& Frey, B. S. (1985). Economic 
and political determinants of foreign direct investment. World Development, 13(2), 161-175.

- $\quad$ Sekkat, K., \& Veganzones-Varoudakis, M. A. (2007). Openness, investment climate, and FDI in developing countries. Review of Development Economics, 11(4), 607-620.

- Shamsuddin, A. F. (1994). Economic determinants of foreign direct investment in less developed countries. The Pakistan Development Review

- Sokang, K. (2018). The Impact of Foreign Direct Investment on the Economic Growth in Cambodia: Empirical Evidence. International Journal of Innovation and Economic Development, 4(5), 31-38.

- $\quad$ Swedenborg, B. (1980). The Multinational Operations Of Swedish Firms. An Analysis Of Determinants And Effects.

- Treviño, L. J., \& Mixon Jr, F. G. (2004). Strategic factors affecting foreign direct investment decisions by multi-national enterprises in Latin America. Journal of world business, 39(3)

- $\quad$ Tripathi, V., Seth, R., \& Bhandari, V. (2015). Foreign direct investment and macroeconomic factors: Evidence from the Indian economy. Asia-Pacific Journal of Management Research and Innovation, 11(1), 46-56.

- $\quad$ Tsai, P. L. (1994). Determinants of foreign direct investment and its impact on economic growth. Journal of economic development, 19(1), 137-163

- $\quad$ Tuman, J. P., \& Emmert, C. F. (1999). International Journal of Accounting \& Business Finance
Explaining Japanese foreign direct investment in Latin America, 1979-1992. Social science quarterly, 539-555.

- Walch, N., \& Wörz, J. (2012). The Impact of Country Risk Ratings and of the Status of EU Integration on FDI inflows in CESEE Countries. Focus on European Economic Integration, Oesterreichische Nationalbank, (3), 8-26.

- Wang, Z. Q., \& Swain, N. J. (1995). The determinants of foreign direct investment in transforming economies: Empirical evidence from Hungary and China. Weltwirtschaftliches Archiv, 131(2), 359-382.

- Wheeler, D., \& Mody, A. (1992). International investment location decisions: The case of US firms. Journal of international economics, 33(1-2), 57-76.

- $\quad$ Yu, J., \& Walsh, M. J. P. (2010). Determinants of foreign direct investment: A sectoral and institutional approach (No. 10-187). International Monetary Fund. 